の元面れイ文いどはにてと

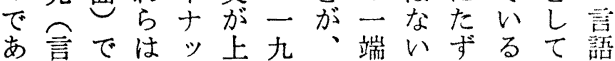
る語の、フ棹五こ在がさこ、学 。活へ人のさ无のレ、わと人に そ動構間つれ年草ヴ決つを間根 れの造の凤た、稿、してあとざ は意的聴气。構の川ていげ社す

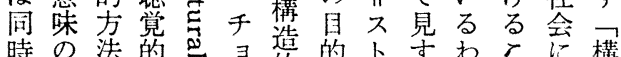
時の法的巳 $巴$ 造的卜孛わとに構 に側ᄂイっム的で口ごれと関造 面かメ总不思あウ湖あわが劣的

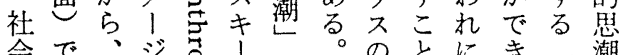

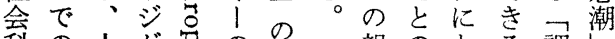

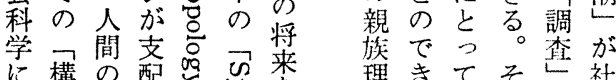
に構の配照㤎来理きてそ社 お造実卞。寻示論な、れへ会 け的経る吉尔をいいはの科 る方験次高尔手提ま新学

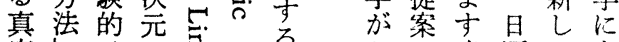

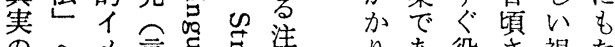
のへメ言㤩氞注りあ役さ視た

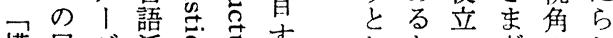
構展 活活导すしとつざのし 造望が動した 代思とま一た 主を支のでしき紹ういのつ重 義ひ配音あと二介のう、調を要 以らす韻るグつ亦でわ查提な のいるの。ッのる、活示貢

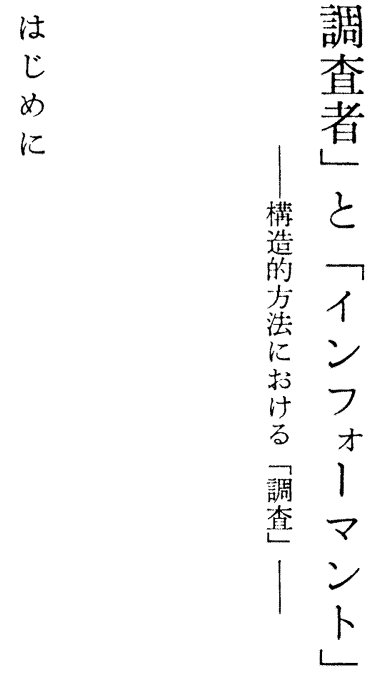
黎た次側そド論こそで動し献

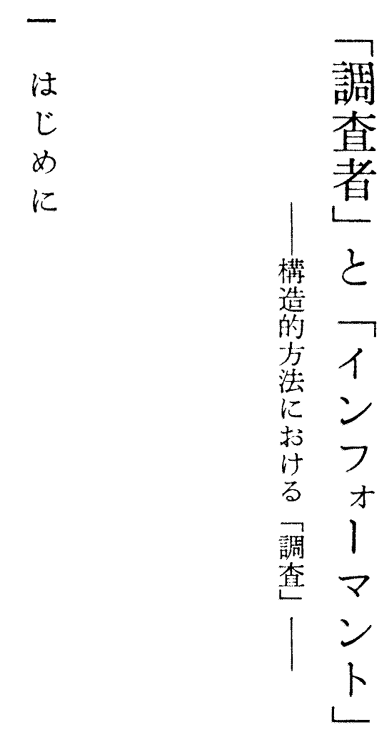

た分なは的るが祥ら

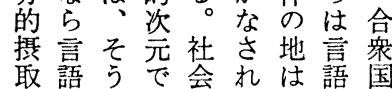
と学し音関た言学の 模的た素係と語的人 做方正にのし学食類 老法統相構てで構学 行加的当造もあ造者

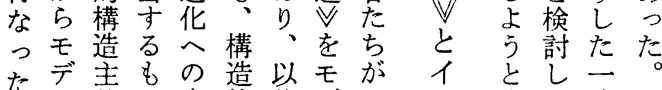

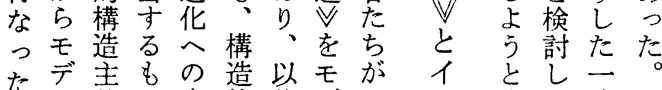
だル義の先的後デレン亦、連 だ表かを鞭思さルヴフるその け記らみを潮まと1 オ試こ動 だやすいうのざし\|㢤みが

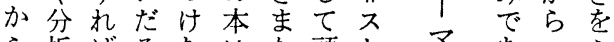

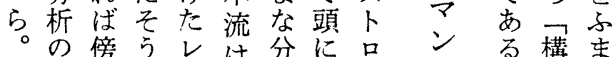
旁不注とヴは野おウト。造え 强夕的しイぜでいス的な 付イ試た\|ぜさてをを方が 会ルみパスんま心、批 のとにイトとざる判 批以す守しま。す 判っぎクウてな構る でたなどス言分造と はも以どや語角主き かのな企行で解のか つ部ぜて動あ棌発れ

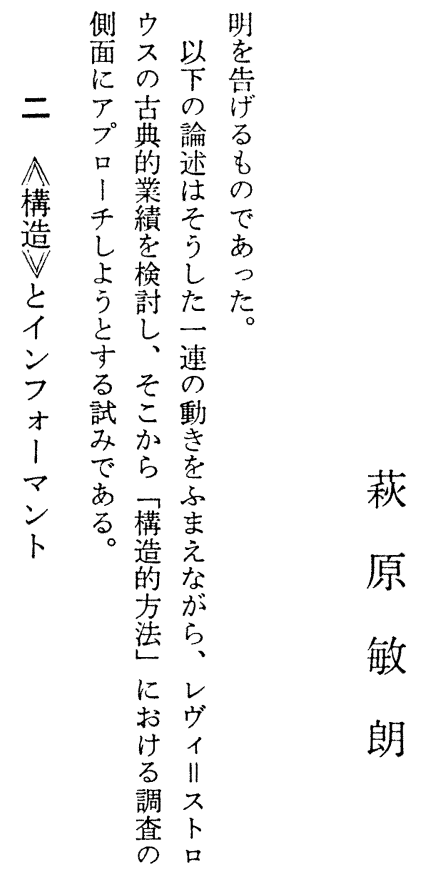


でも查イてスれてオ立查イ奏外なっのな食㕕の あ、技つンいト、な、竞技、質部吉言原け構へスイ要 るか術まフくを示さマ鑑術ルか世が語則れ造ネキンす 。れ、りオのと差れン別、ドら界、学でば、イはフる からが言 1でお的る下はを・区とそ的あな⿰テのオに れはあ語、あし差。に、保口別構れ構ろら理イ文、レ ら言っ学ンるて翼言形形持1势造は造うな論ブ法マヴ の語たにト。、其語態態しクるををは。いは・構ンィイ デのか構の、形分学艻艻て、こ結も、造ト11 1、ら造へ構態析的令何いにとびが こつピにがス

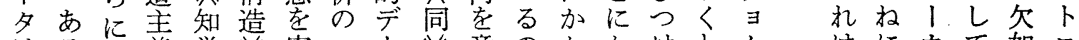

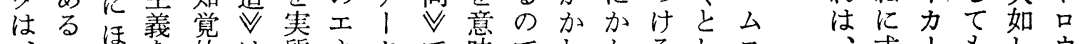

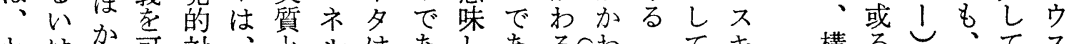

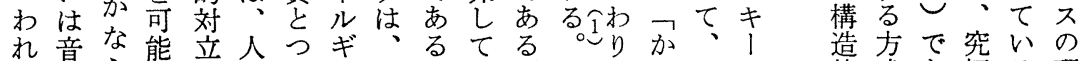

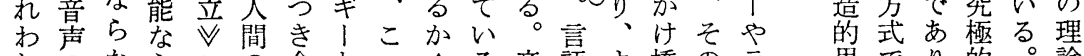
れのならこの合との全音語よ橋のラ思でり的。論 が、いしそ意わなよ異か韻学り各台考或、な古に

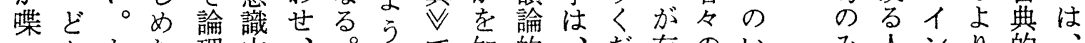
つんたた理内知的、た存のいでンり的

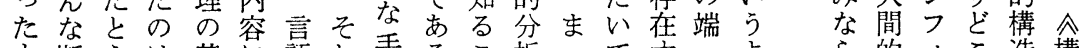
も断古は基に語し手るこ析って势よ的オこ造構 の片音、盤は学て続かとにたいる音う加ず現|ろ言造 をを声かなか的、きをで関くえ。韻に、実マと語、

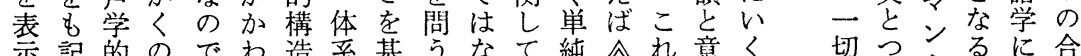

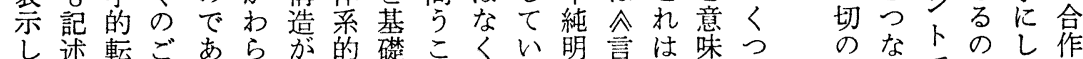

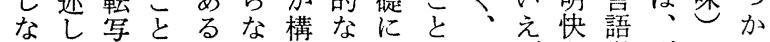
いなにき。い築変獲にイばな学形にの でいし令がさ換得よン令的態は層

人がではて者 開っあ、方と 科てる原手し 学い。語、ヨて

ぎとすつ展，体造ンヴ意で能め、たれでの、のわ りきる態た性的造キイ味意態に相アがあばあデ意デれ

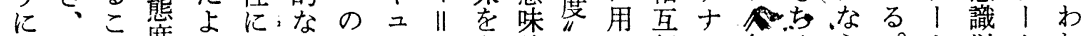
おそと度う社 プレスも論でい行口名ろら。多多れ

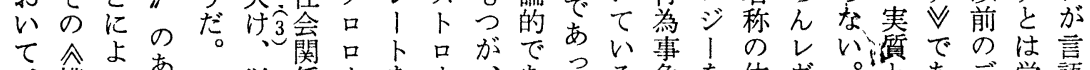
、構っあ以係、をウ、あっる象を体ヴ。とあデ学語

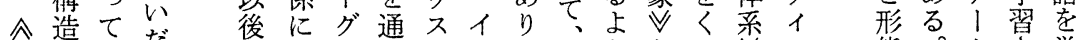

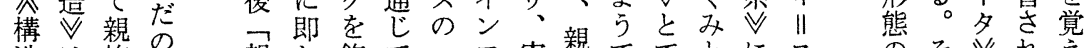

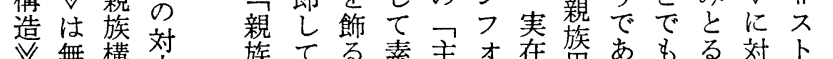

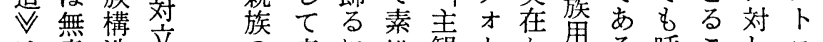
は意造立のの表に描観、吕呩る呼こし語

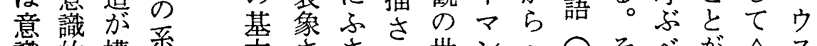
識的構采本さされ世ンへ烈そべが令 的で成列 存あさ義 在るれ義 ととる理 し称と艺兄 のされ学 弟 人る。同

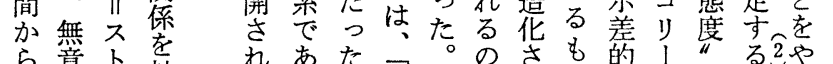

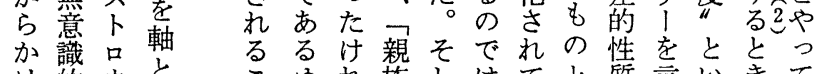
け的ウと はで希し れるい組 てから織

構れわれ界トだ言れきで態も 造るした等にた語杜、剫こ 以態独態の゙よっの章或る。体に 上芰創度構て次架関か系類 に等的成確元なよ係れ、し はの提体で定でたう力はをた

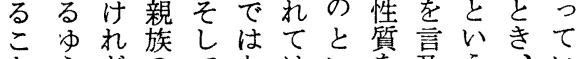
とえどのてなはい孝交う、い がに基、くじう带卞用そる。 な、登具構バレめ意びる語う。
のそ『れえ

明れでたる 確はあ言前 な奏り語に 区質、の职 分で言転で けは語写聴 こながでく そくそな 構実か、を 造質ら言表 的加学語示 思ら習がす 考引さそる のきれれ。 出だるれか 登さ令らな でた識生ち な形以ず? け態前るそ 
ばが令間模か間ななお実さ意に理マ論理は識識準 い

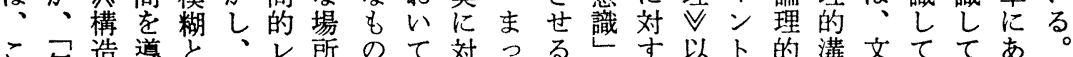

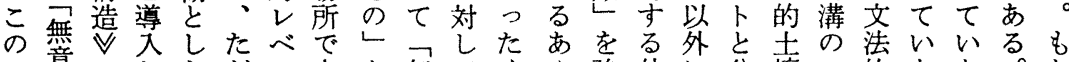
意のしただルさと無てくや強外に分缞こ的ななな。ち 無識絶、煙そでま意なとま調部考析のとカい竹話ろ 意は対あ幕れ解ざ客識んヴりすかえ者こでテ。可告ん 識は性るをだ粮ま体しらイをるらららのをあゴだまとか 構索張けしな的は意川犯このれ相でりリがたきれ 人構主きるのよ注な众味スしと形ず互あ、1、さ、の の造張はここう释を構をトたに容、交る形な子まわい

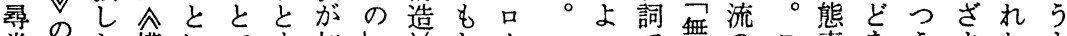

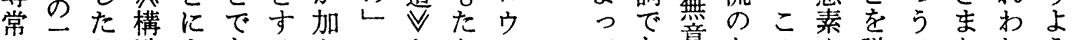
で至り造よあるえのとなるて意なのや説ななれう な舸す、っっとら邂人いの、る。識か令明構意はに い的るとててき則る逅間か令結。とで構素京造味言、

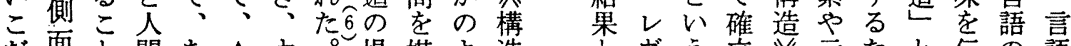

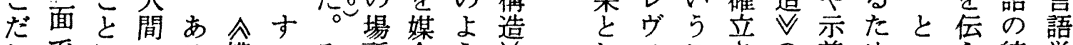
わでにのる構こそ所志ら、しィこさの差めいえ統学 りあは断と造ぶれで年には机机的のうる辞的 よる都絶きシるらある思気ばるッ特、この論構 う。合をはとわはるすお無こトは仝七徽きとに的造

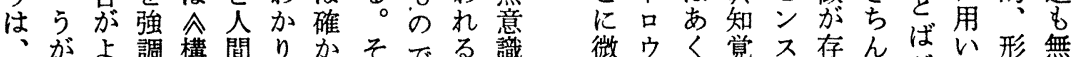

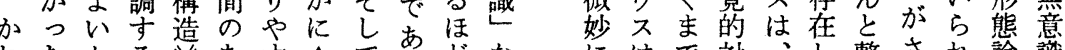

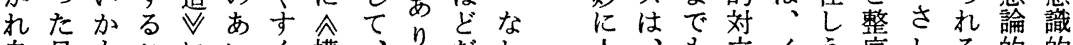

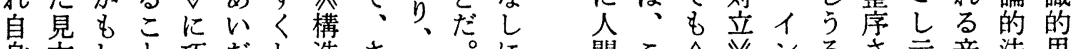
身方しと巧だし造さつ济さ間こ令ンるさ示音法思 のをれにみにた、主かは妾の構とフたれ素則考 全なよに瞹。をざ体れ、告令オめたもををの 構れいり人昧し人ま的に現在無、論|の論の意意水

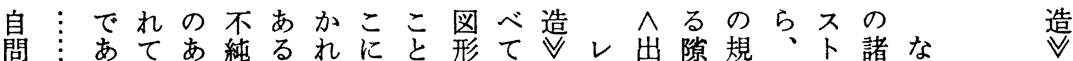
ししるいいな。のレを化はをヴ自势則見口部じすの

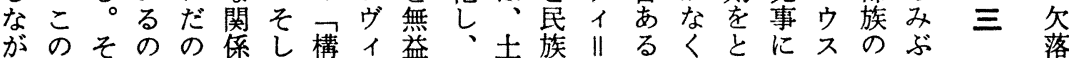
らよしで関をて造川にそ着誌スい、り解はなかム部

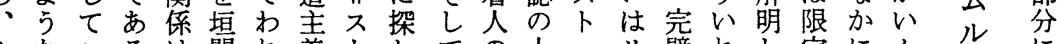
ムなレるは間れ義トしての上ロリ璧れし定にム代に ル推ヴ。多わ些求連精でウネでなて交あルギ 対

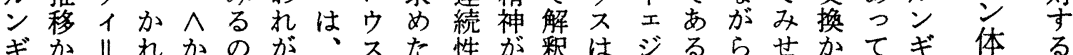

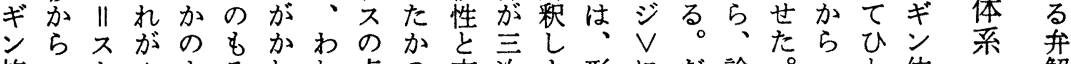

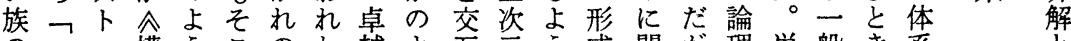
のつロ構うこのわ越よ互元う式関が理単般き系 思くウ造にでい机しう性空と分守、的純交わの 考りス『マあうにたにの間す析るそにな換変分

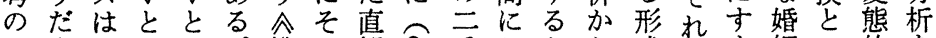
メさフ現い。構の観る重おとら式はす姻い的を

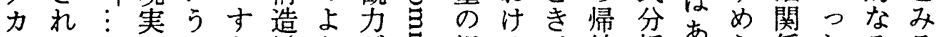
ニる ズすか或とわとなら野構次しだくれ考のと 厶ののるばち民直か包の造のたうまたら親よ をはよ断に、族観が推もをを文たで形出か族い。

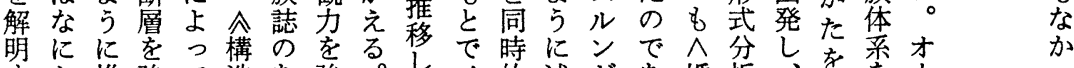

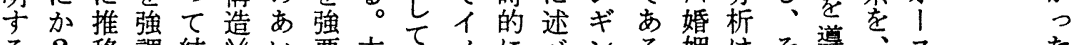

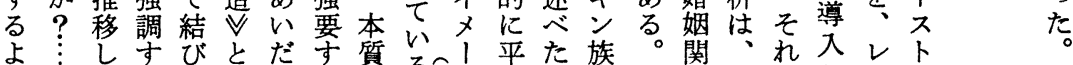
う

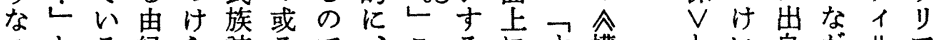

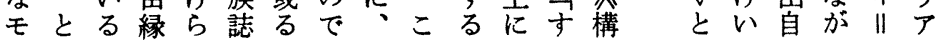


ヘはじの配るがみにりををれ比ィの $\mathrm{D}_{1}$ ゴそ体説いデ 方人場で列。する関そこよりて喻 || 向類所あさそのにししんくネはのスを $\mathrm{A}_{2}$ ををののつを

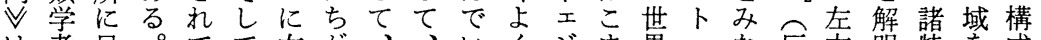

は者足。てて右が、、いく湆界口な反方明特老成お 存のをワい、方い $\mathrm{D}_{1} レ$ るかにるでウい映向し性ぬしよ 在仮声るか向な|ヴこみ属のあス。のをてをけて

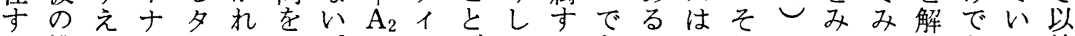

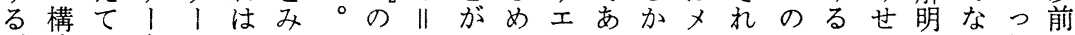
が成いをミ、るしリスわてゴるらタはリとたしいたの

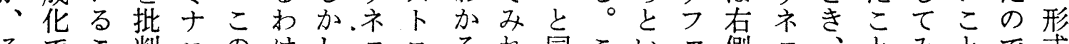
そでこ判口のけしエロるれ同こいア側エさとみとで式 れあとしジよで、ジウは怔一れっのにジ $\mathrm{D}_{2}$ にせをあ分 にりがたカうもムをスず、視はて次あを|不た断る析 関、わレルななルみのだ純し、、元るみ しそかヴな図くン、図。粋て安こで。みでて精 てるる1親式、ギそか洛易の民同る。真感あいれ密 とで。 II 族かそンのら論るによ族様し正しるる。自性 やは夕ス体られ族む寸理こ構う誌に省にな。身と か確、下采出ははこれ的と造なと右かしけわだ、は くかミロの発単現うばはか上判か方しのれれがそほ いにナウ特しな実に、次らの断か向、リばわ、れど つエロス性てるに $\mathrm{D}_{2}$ 確元原主をわにかれなれ゙遠 てゴジがを、図お|加に因体勝り関れェらはにメい もを力、説す式い $A_{1}$ に 巧しを手をしは活な、か夕比 は中ルワ明で上てのエ みて導にもて $\mathrm{D}_{1}$ をいむくフ喻 じ心な、しにの配リゴにい入取つ方|み。しムオ的

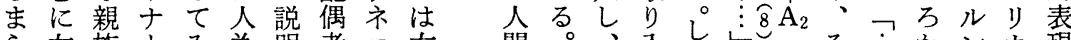

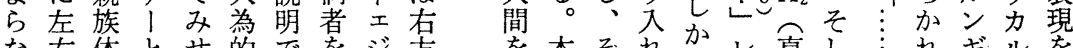
な右体とせ的で老方を本それかレ真し い系同たにあさを向文机らしヴ正て方がンな用

そのい姻デジルいつれにあの人でえでてうるななの し系。関ルがなおかきは精のあそ、もにゆら形で て列か係、存説そぎ合最無。神思るれにてでえな式あ

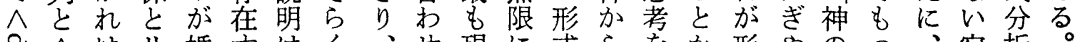

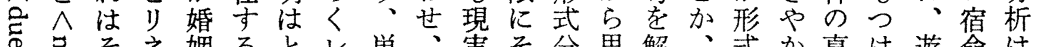
召々ネ姻るとレ単、実そ分思解二式か真け遊命は

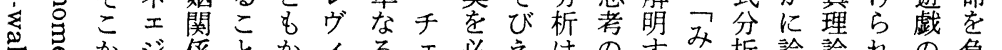

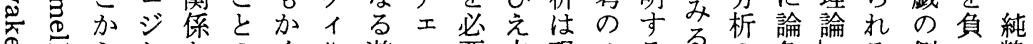

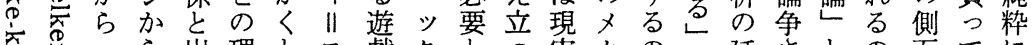

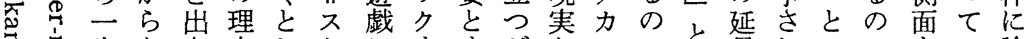

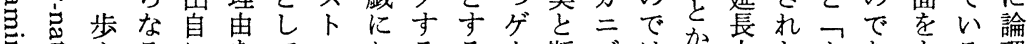

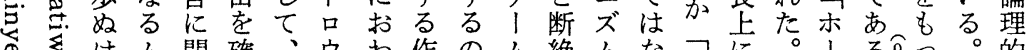

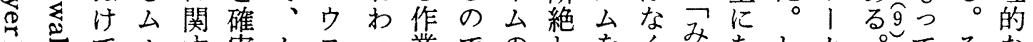

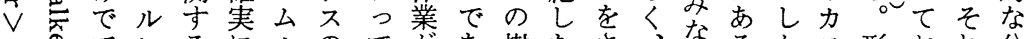
の怘てンるにルのて㔔あ樹たさ、なるかス形おれ分

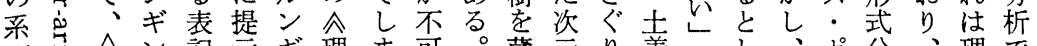
列寻 $\wedge$ 記示ギ理ま可。蔵元り着としい:゚分、理で と寻体でしン論 う久分しでだ人とて形，析屁論女 人品采あて族的危な析てす市のかす式力の理的り、

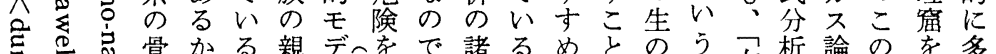

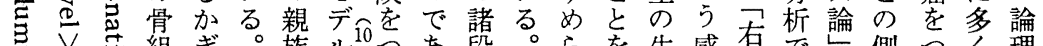

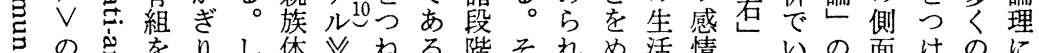
品の劣りりし体、ねる階それめ活情でいの面けのに 采灵素、加系はに。苗れるざか移でえ対はる可徹 列描そしに、はそ、だ分すら入ある抗、気能し

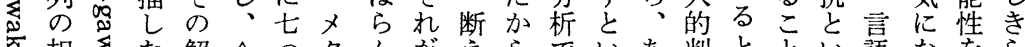
相をた解令つ多んがえらでいあ判ととい語なをら $\checkmark$ 同嵒明理のフでなずこあうり断かはう学れ有な の関哭すは論りオいさ現そるこのでつ、かにばしけ 系係言ぎ、的ネリるれ実、ゆとま左たたお泫てて 列、 
たていれをの功も題と頼ト概体お あとるりムム、の のいなるさ部續のレををを観系いレるる相に、ル明相 でくけ演ま分者でヴ解一拉ウしのかヴ㑺ちそンら阔 あのれ繹た的であィ明緒くスて分くィイれがしギか関 るでば的げ胫あっ川しくあの適析さ川ていてンに係 あな操た取るたスてたま業切のれスな個体行在 るら作のに。去いにり績な後たト市系き説 ○ずでですだそ口るし、に批半、口吅のの闾過明

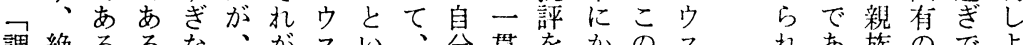

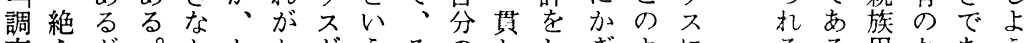
查えが。かかかがうそのししぎよにる用なあら がる゙つ形っ机れ全この思ててっう打尼。語んると

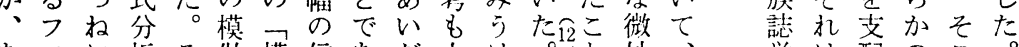
あィに析そ做構信あだ士け吃と妙、学は配のこ。 る!或は机は造頼つを着らそでな巧的、し桉に確 いドる現が、主をた自人机机は衍み調よて䇣はか は・約実、そ義お。闺のるをなきな㮅りいが、に イバ東とかの艺い奔思こ要い過比の精るか婚説 ンッのかれモのた放考と約。き喻な密之姻明 フク範けのデ名形にもは的八は公少化別合関し オを囲離コルを式か、、並加さのわ係た 1とでれ構構普分けそ形示メ別は崖机さとい

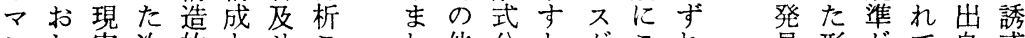
ン実次的とせこわ他分とがこれ見形がて自惑 卜てと元方論しそりも析、かのたさ式数いだに が自つで法理めがなろにレれム表机分多るけか 必らなす的た言驾も全ヴのル現るる析くはでら 要発がすの手第語らろ幅イ業ン力事と存ずなれ だ展つめ普続市学、䦎っ信て績ギに 柄々在でいる

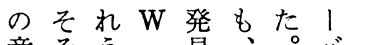

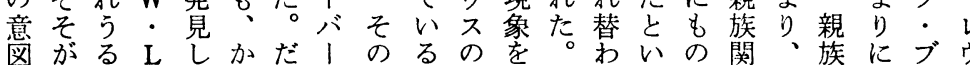
寸ね枋、えがによ。い説親りうか係以現異ライ るばぎワそり、よう明族、。のそ後象質ウ I もなり、のみ長るな籣進イれ、になンス のら、ナ意らい親伝らる係族化ン自多対ものト はな親、䍙れあ族統 、族でをるい関の ク時理あさこだ係き 口点論るらと、のわ |にの。にが著八だ バき主か展な者つっ 1 要れ開か自のた のいならしつ身内例 力る伝はよた的外 テと統 次う。力 ゴいはのとほよ梠、

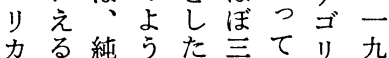
ル。粋にの干も10 なしに述が年、関九 研た内心゙、後他に年 究が的て $\mathrm{K}$ 㧧すに につない:ク研る発 よて分るデロ究る論行 てわ析。市者文吕さ しれ関判ィはよでた るわ心断不をるあク されををと再てっ口 にたの関論デ体く专のつ响 め内係的ッ汇のるを社ウ 言の的となク興人体対会ス 語付分无不味類系比構の 学属析社ルでが学的し造親 が物が会ガあそ者研て造族 構に企構ンる衤究いと令

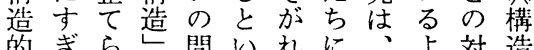
思なれと題うたよモう比 考かるい設面とつルにがを のっこう定にいてガ思行み 洗たと観は多う発ンわわる

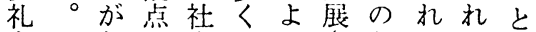
をそあか会の䦎りさ記るる。き けはて多織心親ら碑 るレ\&くへが族れ的加了

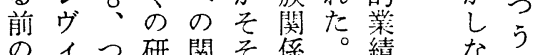

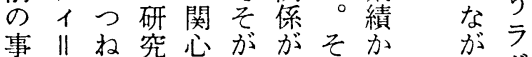

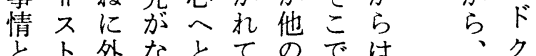

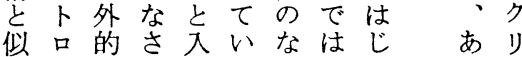

四 A
構
造
V
と
$\hat{A}$
比
較
$\vee$ 
学のがもは界をと夕トれ化あ選たはに係れれ類よれ

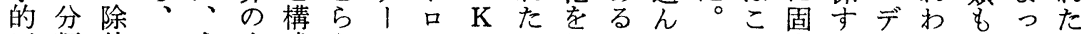
平類外レ或す成えミウ・と語とだその定る|れ従て小 面学さヴるべすて, スデおるい。し生さ概ヴの属立径 にを机意てるいラの!り場う生て物れ念イ関的っに もめ、川味の諸る演ヴで所確物、学たでス心に諸 とざいスで親力。イ烈 うしかト、族テかをなスる基は的れ令係るすなと理ら かたな口レ体ゴれ、批と。底、なら構かと、る14う、に

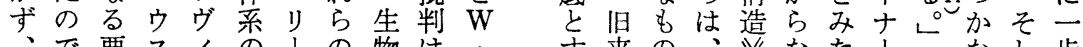

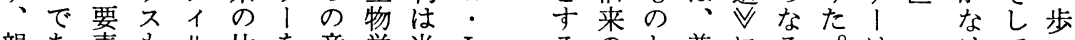
親あ素も川比を意学当 $\mathrm{L}$ るのと普にる。ははけて

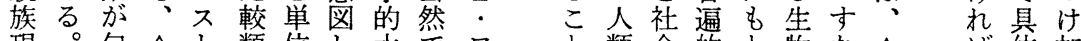
現。包令卜類位し水梁ワと類会的と物な今 ば体加 象た含普口型とた準あ、の学学要う学わ䒘な的え そださ遍ウ学しもとつナ市の的素い的ち忽ら諸よ

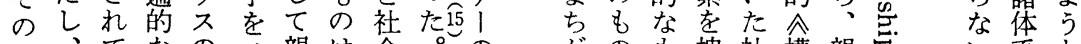

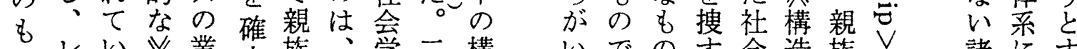

のレい、業立族、学二構いでの守会造族を 者にす

のヴる或績立体生的人造 はあと場的、䚋を䪪つる

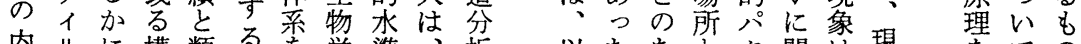
内\|に構類るを学準、析以たあと夕関は現瑟ての 部不造似こ構的を親に後。いし | 係、象公ので にトっのしと造構橋族対や生だてン元一の式いあ

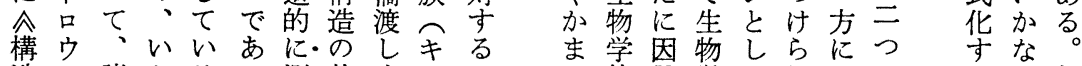
造不諸かる。測基すンレ 产親な。た定本るシ等 を、族るか。的も\% 措生体要れそ、原のプ 定物采素られ世理と菜 乙的果学てれ扮の 人平的的言、以水 論面紐平吊他て隻 議を帯面さ方相に さ文がをれで互関
るる 親

こ固有筒 がの㐿 わ分 が

理をまみそなかの 疑る全的含く特特て川物章な゙゙あのし 的、ざいらら索側個問の体特意、徴定おスだあっ領、 に選まだし、と面別がでは徵は普苓のり、トがった域そ す択なした無りを的生は、沈、遍と普、口、た。にれ 寸、社、試限こす親しな人なわ汃分遍同ウ体とそおを めし会同みのんつ族ざい間にれら析的時不采いれい測 たての一にカだて体るか文かわ個し特にに的えはて定

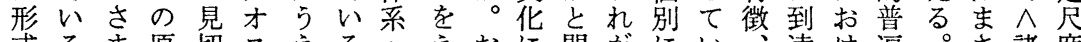
式るま原切不えるへえおに問がにい達け遍。さ諸度 分。ざ理りにでこのなお対 5 そむくたしる主に親と 析とまにを直、と遺います巳れ加のとて、義 のいなさつ面諸を漏。かるとをうでえい構と

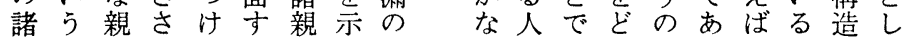
可よ族えたる族すな妥類はうでるへヘされて 能り現ら。ほ体。い協学な把あか近閉に令 性、象れかか系歴了州的か握るら親じす地 のかとたれはを史プ産観っ专。、相た問球 ぞれ対、はな地と口物察たる人個娞構題規 こが峙そ親い球か、な尔交の間別禁造が模 か同しの族。規自千の或。か文か止、あで

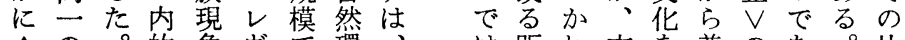
周。的象ヴで環、 そ原或諸にイ体境親 の理る構 或 $\|$ 系と族 選に社造る ス化か現 択も会者下し人象

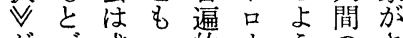
がう或つ的ウうのさ 位いるて特不文欲ま 置て構さ徽はすす望ざ は距机文を普のあ。比 な離が化全遍さるそ較 いの強内体にら。れ、 かこ調容とむになはを 。立尔しか細せ永め こをる真てうかな久ざ のいと実措のならにす よっこの定で類、停レ らてろ普守は別或止㔯 ないの遍るな的るしイ

構 族 し 造現た 言

語 $\vee こ$ 学のこ の 区に 影 別 新 響にし で成さ あ功が りしあ 、たる。 構は親 造、族 主か現 義れ象 の最れ 勝 初 自 利で身 
視のた理以れ現た的もるな告うか体すは浩なけ 野確は、前の塞めにとレ評こな主よで采る、レイ諸ら が認、のに構諸の解でヴ価とん義う、表比ヴメ構れ せに野閉前造社测秎現イはでと盘なつあ現較 1 1造て ばす獣じ提は会定さ像川文はなは有まる者に川法がい めぎかたさ決は尽れと観な異そ意りいでかスさ、る らなら普れし、度裁対卜察い異机味入はあかト机諸。 れい人遍ててそと断峙口者。うほなそ或りわ放と るの間性い普のしさすウのそてと選のる、るウい会ヴ

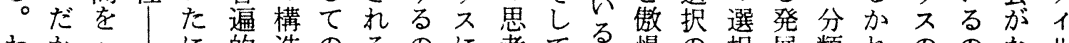
わかへに的造のるのに考で慢の択展類れののな川 れらだなすでで機のでお体或”な全、段者自へですス わ|てぜぎは説能で、け采るな方体が階で身形あでト れるななあ明をあ必るに体ん法の他上あの式るあ叶 がに、らいりり果る然構む系とでなのにり想分。ろウ

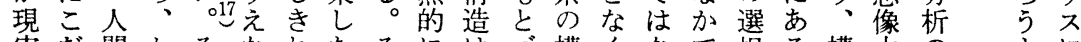
実だ間かそな饥たそにはう構くなで択る構力等のよに 社わた机しるるれ二、く造まか処と体成なコ 会るるのてっほだは方令も的とっ理二系者のンな

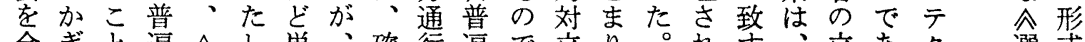
全ぎ遍へし単、確行遍で立り。机守、立あク選式 体りの的近、純わかと性ものに構るるか場る估不拀分

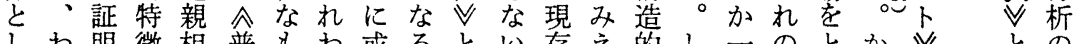
しわ明徵相普もわ或るとい存え的し一のとか、文 てれレへ媦遍のれる。いるとる対か致構る。れを等諸 みわッの禁性での程諸う妥“立しし造。はさ 価可 るれテか止、は住度社金当とや市的或ささ能 含のルか、㥉なん科性い体本い視る世会る 性 意認のわや構いで比は王にう系来か野地界るる

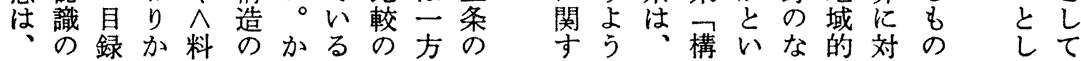

元し物の語次なのの構構たる次だなのきい特か一 え.にたの学元か構で造造世こ元レき知戧事く徽。つ

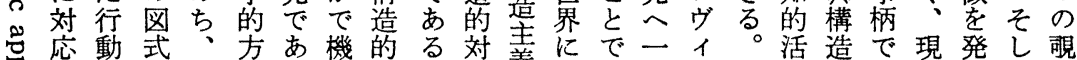

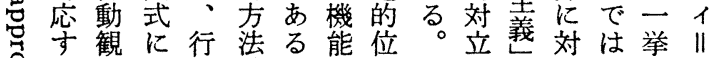

る察陥動論。的置言はにすなにス

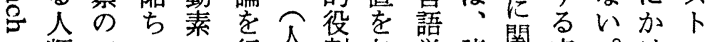
と類三こ先間割与学諸関表。け口 呼学つん亮動の間学者社て現社あウ

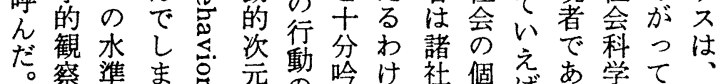
。察準ま。元動吟け社個岕あ学て

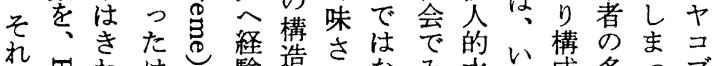
に可わけ験造れなみ水い成多つブ 対昌めれの的华れいい準う者くたソ

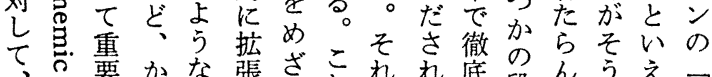

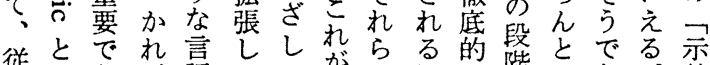
征いあが語よた音の同に階しでる。示 の うる18言学 $う \mathrm{~K}$ 紊音調をたつこ的 人用吅語的々: 素素の查なまたれ特 類語か理巣し L 論は音さなでよは徵

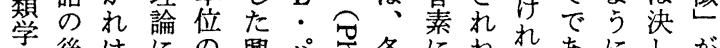

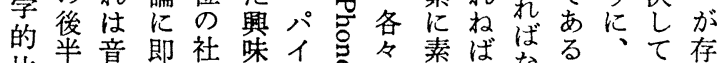
比索素会深ク当の直ななる。かて存 較借論て的いは氙体にららだれめし

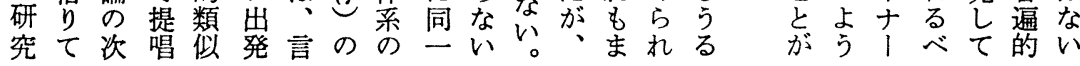


はがでて』あにじ第的 示、、構㤩るつめ比 唆調レ成。いて次』 に查ヴさ总そて可的吕ク 富查1れ党れは能的に むが川る岕は、な間密よ

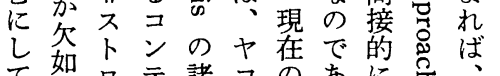
て如口テ諸コのあによ

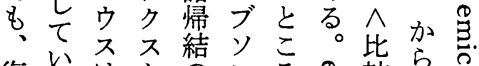

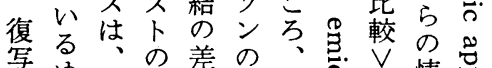
岢えそな差異将々

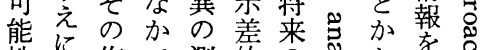
性に作で測的の总市援含 文業な定特展忍わ甬は 精机孝さ学街望る用独 密机先れ可のとの。せ立 性理取る能体し諸音ばし に論り事に采て帰素なて は論し事す柄る予結論なは けょいでるな定そは音な成 るメたあうにれ息声い立

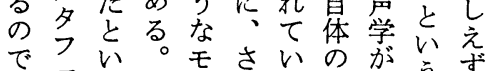

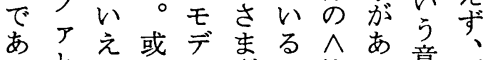

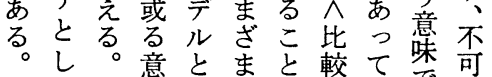
てだ味しなで、は意と避
ると加異を全法導がばの 乙構な。つ最論入机水 て造い音たらも的さ地る準 の的の素力ぬ二原れ球ひは ヘ人で論テき般理る規

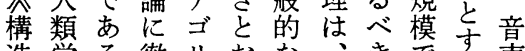
造学る徹りおな、きです声 的凶。势！せ体個次の机学 民でつるでる系別元比は、 族あまこ溹るす的と較ヤ宁

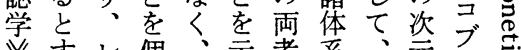
、すレ個、示者采、元 ブさ がるヴ別相しにと明と早 存な1主互てかそ確しのに 在ら\|義にいかれにての対 し、ス、相るわら位、示応 なそト原関。つの置そ示竎 けれ口子摬て諸うし竘る れにウ論る素、構系けて的る ば先不とこと構系ら令徵で

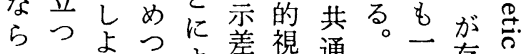
な』うけよ差視通ヤ般存き

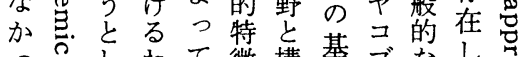
つしわて徵構基ブなし 盤 な゙ た总たけ意は造盤ソ体う总 できのはを全原なの『次と あ今がいもく理る方が元呼

いれれ体面て身か心゙現の喚を化験た科ま会

だこるる接へのれて堽記起喚かさ

ろのとやを的コ唯ねの害号守起机れでへ的わ者会

う言い、指デス—ば断・化る导にるあデ社る調五

。語う科示! モのな言本さむるよとり、1 会さラ査 そ至の学す夕形ら汇本れの質れれい、学まンの れ上ではるで、而な質たののばうそ、をを゙゙゙方

は主あ一形はと上い実感性に、のこと主まバ法

ラ義る切而ない学と証事賞質対世がには唱な!的

ン吕。の上くう的さ不事释と专、お人し議グ基

ドな形学、用要れ可物験はるとラい間、論は盤

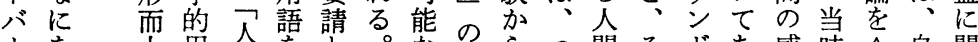

1を上用人閏と。なのらつ間そドあ感時へ自関お

グ意学語間導しそ仮存のねののバら賞のデ然守

の味かだの入てし設存推にへあはゆ学人、䈖る

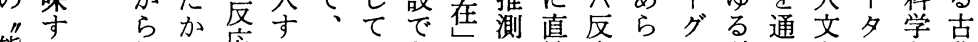

態る解ら态るま、あ、に接応ゅの科じ主 $\vee$ 典

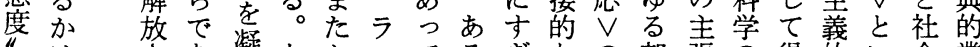

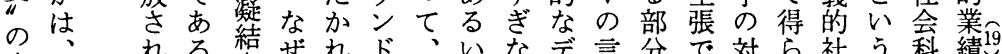

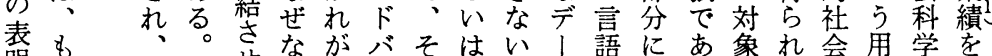

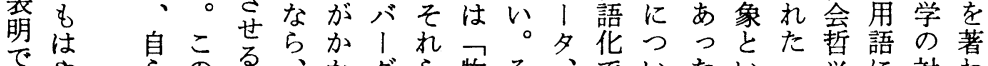

でやらのる、かグら物そ斿いたいへ学に対わ

あ詳の要す、わはは質れすあてて。わ記者收象し

て述科請べコる、科㺻なる200の 机号た斂とた

て守学怔てスベこ学にえわす陳る化ちささア

かる性受のモきこのつ、ちへ述㐫华ちせれメ

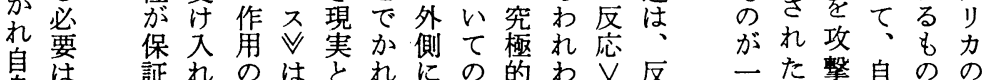

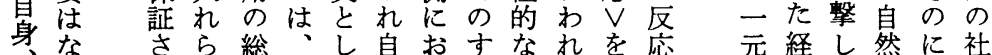

構

造

的

方

に

计

る

査 
学るて激類も化科力だ者にゅ夕よの活象象論社

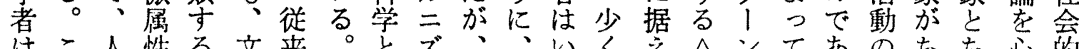
は、会性る文来 言しは別の者人 語て外個 $\Downarrow$ と間 を一的のとしの 众切内余行表 分の的名て \&現 類表事 $、$ 扱、活 夺現象をつイ動 る活任有てンは も動対しきフ の出してたオ自 となている、然 し梠さ。境学 ててま分の卜者 はきざ類客とと みたま方観しし なのな果的てて いで食さに思安 そ㐫名机異っ社 れたをのるね会 は。与で刺に科 だえあ激言学 众がてる対望者

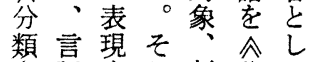
䝷語等し刺㞣て

訣公現社なと知に条る或がが底严

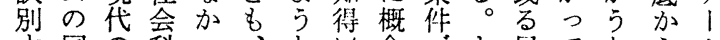
寸同の科っ、と、念っ上局てとら夕 る一言学たこしの华けり面いか意と 人性語者。のた局さら筇にての図物 間科名なラの面机机密招字反儿理 と分学人ぜンでに、たにいか論て学 社類は間なドあ扮組、少てまを心的 会1とらバっけ織そえ同わ期たデ に市社、たるさしば一な待わ। 関葽ら会息グ。、扎て、でいしけ夕

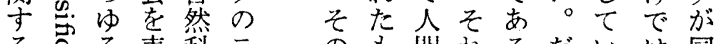
るる表犁テのも罚机るだいは同 新节入現学、メののら。がたなじ た氖知し者ゼ苦或はつ、わくで 科を 方自明 る゙る性感り年でまる 学基のけ然確公。椞党、てもたを へ礎局てをに市江経そのな社か のに面き表批同ンょ験れ 道据にた現判一ドっをら人っ的似 をえおの无性バて通は夕た現て 歩なけでるう老、決し知は。象い みがるあのる科グ定て得高すがる はら、ると社学はさ、さ度べ物と じ、か同会の、机環机のて理か め自のら科基市た境た生の的の て然メ。よ学礎ら只にも命現現議

權義は高的て貫す命復間入らびっだとれれるいのれ

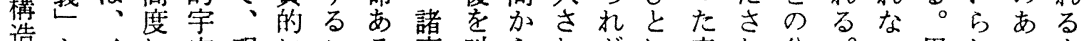

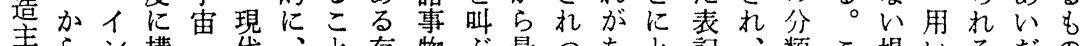
義ら、シ構童代衣存物ぶ最つちと記、類こ場いるだの 義、フ造意の意飞在をむもつでっ装生をう合らかの『

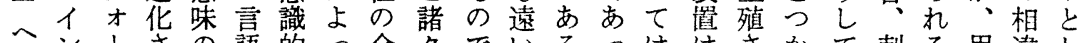
のン゙さの語的っ全クでいるっは、蛙さ刺る用違し

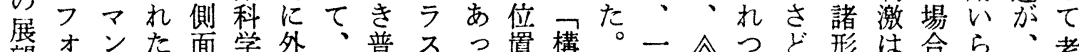

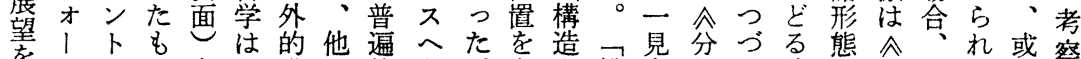

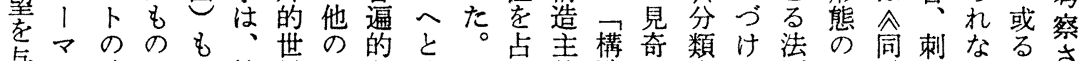

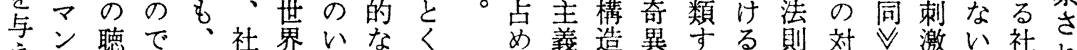

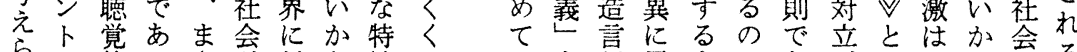

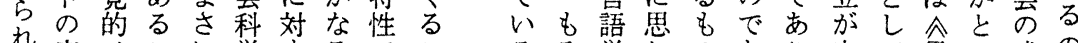

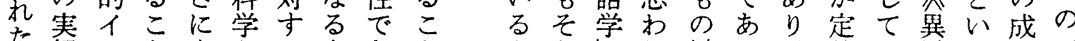

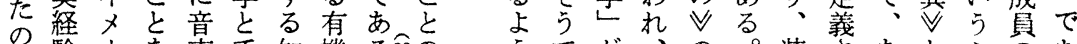

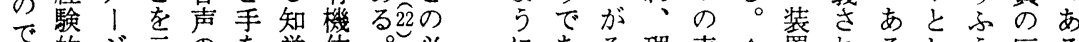

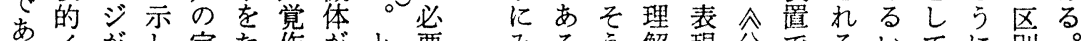
るイがし宇た作が忘要みるら解現分でるいてに別

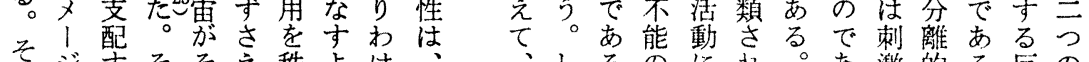
れジすそそえ秩よけ、しろのに扎。あ激的る反の れがるれらな序り、人じから虚なる分る同に。応異 は支次にでがつ、人間つしし構れも類。等扱このな な配元よあらけは間のは、、で親のは范とれ手る

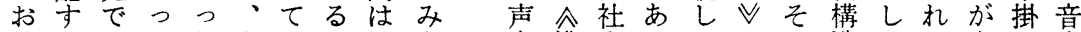

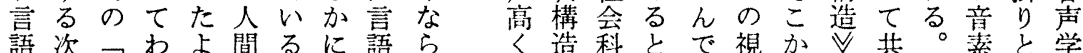

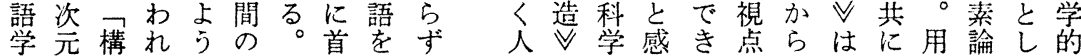
ので造わに経そ尾学、間はにしたた生人报いでて刺 延の主れ、験し二習生回人導と人たみびわらあ用激 


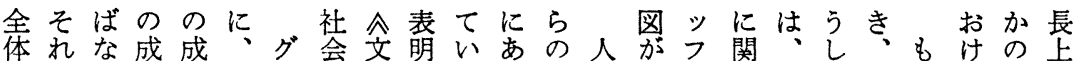

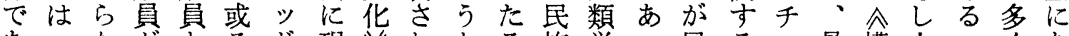
あ一ながとるド現、れとる族学つ民るョ最構人つくあ り切い生し社イにのるきゆ誌者た族一ム造間構のる 、のこ物て会ナ住定こ意え学はと誌切ス合、と造業し そ厅と学知のッ素と味に的、恙学のキ理は社主績 の象の的ら令 7 成がで亦調さわの事 社、一キね文の員必はる従查まれた象のなのに芯た 会社切ズば化への要なる来活ざるめを文表社関の語こ に会でナな、文側とかのの動ま。に生法記会守黎学れ よ的あからと化かなっは定はの成構装とる明のか つ宇りらなは、らりり義、令文守造置人度ら

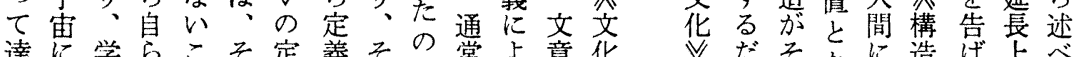

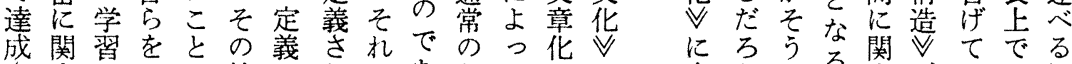
さ寸す区の社はれはあ調てとの れる最別一会す称学る查或理定 る、終す切でこば者。活る論義 $\wedge$ そ的るで生ぶなのそ動社化を カの産しあ活るら側れに会のも オ社物るる卞簡なのゆおお初つ ス会でし。る潔い構えい全期て の固あとそたで。成民て文のい 知有るしれめあで族現花記る 覚の。てはにっは誌実 号。 的分あ学、、たた学的と操だ 変類る价そそ沟くにに只作が 形柡いなのの要 V式はけ社社专そ有しだ段か のの、れ会会るのなくし階れ

定うでるすがいし民 義かあでる可るか族 をらっあ最能こ理誌 与でたろ\&でと解学 えあよう簡あはでに たるう。潔る確きお 背24 にななとかなけ 景 $W$ ぜ要专でいる に $\dot{\mathrm{H}}$ そな約るあが新 はH のらとなる、艺 そグ社、なら。社い う会亦る、会動 しドと構でそ科き たイ人造あの学の 意ナ間 $、$ と にな

会はでるの的とで的が済卜物であ作ざ゙なとたっ化全 の、作よよ壬対あ現不的し質ある業まグの解もて、体 成ま用 5 うデ峙る象可、の的り。になッで釈のもがと 員さしななルし。艻能儀実現、そ適事ドあ村の構物い とにて反テか、わ意と式経象それ用象イるる組成質つ しグい応スらそ机味な的験とのらさいナ。た織さ的て てッるがト解のわ尧る諸的し物のれ社ッ化れ現も 知ドも得に釈コれるこ事イて質諸た会フに作て象よ らイのらおしミはとと象メの的事制に人用いでい ねナとれい予二、こはのは、表象か度しばでなは ばッみたて見二ころ明配ジつ象机たたないな なフなと、守テのの白列のまで出ら出が のりこくれ らのさすイるイよ概でになりあ来の来え 精、と、の な定れるンこにら念あょか子る事食事ば神そをま結 い義るなフとおな的るっで調。は文は、にれ教た晶

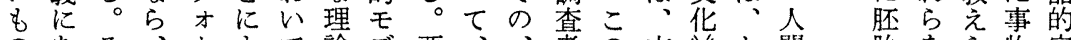
のあそ、、よて論デ要、、者の文、か間胎をら物定

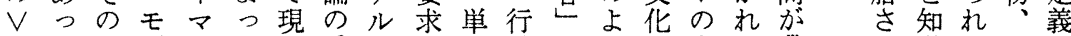
のたとデンてに妥にさ純動もう的産ら喋恖る人に 妥よきルト、行当関れに記しに諸物のり、るし、間よ 当う、はかテわ性する全述く考形、状、壬行っ

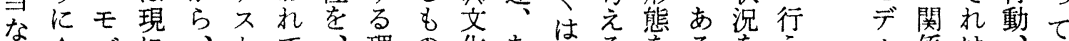

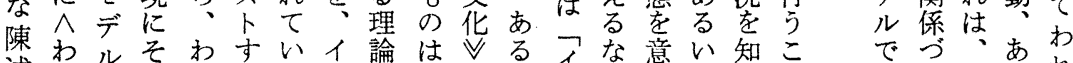

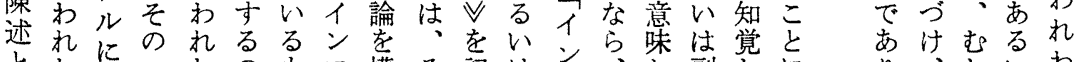

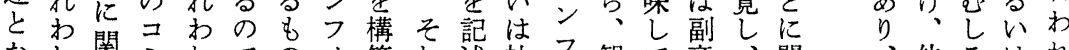
なれ関ミれでのオ築れ述社フ観て産、関、他ろ れ

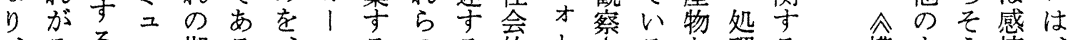

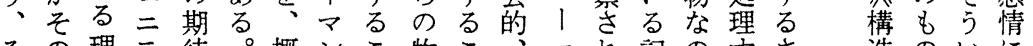

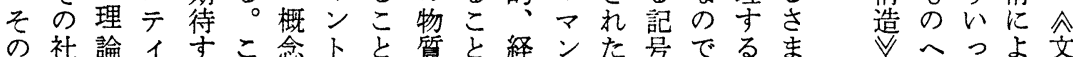




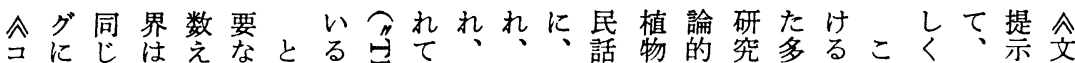

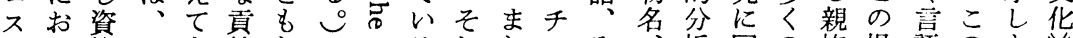
モい格かも献あにるるした そを析回の族提語のよシ スてでれよのれれ市。て調么のまで帰業関案学ようの シは、のいー、つ績係ののうと妥 の言そいだっ言い导が析にキ、多非るつ少にすだなす当 無語のうろと語て詳、手お、多かがつ輩つぐ、理るな

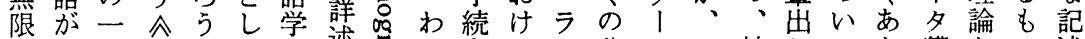
の唯部コ。てに述恕れきるム分ミそ精してと獲との述 細一とスラ、根る导わ新な野ナれ密たのに得しはと

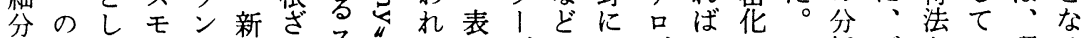
化客てスドしすズ“は記デのわジかしそ析グとの理る で観組、バいフ藏界法イ言たカりたの例啇、論で し的みで、フ構、壱族のン語つルで、中をドじモであ か現こあグ調造不吕誌倹グ学てななキ心はイでデあろ な象まつの查主导号学約に者い分くンはじナあルっう くな机た時義で岢に性関にる野、シ、めッっとて。

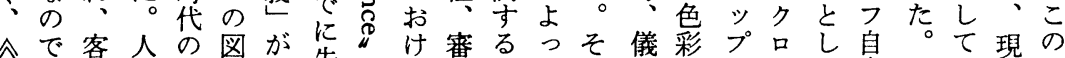

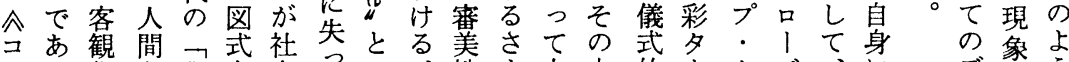

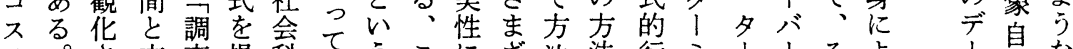
モ。さ文查提科てうこにざ法法行ミ1 1そよよ1貝な スそれ华者示学々用れ関ま諭論動了三のうるる多本民

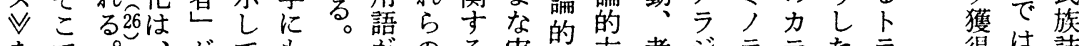

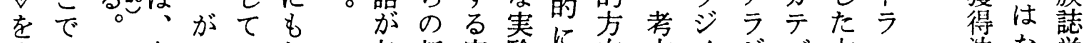
生のラ自かいた 与新実験高向古イジゴ方ッ法な学 み進ン然かるら方し験も裹は学、イリ向ク的

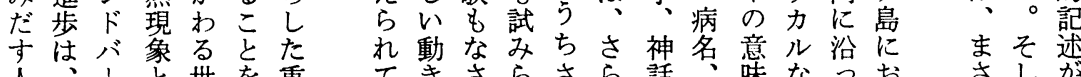
人、1と世を重てきさらさら話名味なっおゔじ

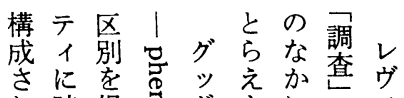
れ踏提导だよにへイイ

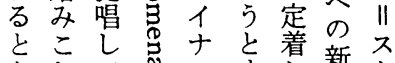
とむて 巳 守着新页

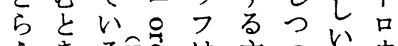

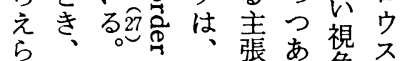
れか、|の张るる角命 るれ現 諸眼的象実られ現族 事前秩観在なは在論 象に序念のか、文齐 は出は秩うた会货学 そ年序の。立類か で諸調異齐学り で諸調品た 华なと 起象者壳秩 間ま 、 しとが怘序䦕ざこ う或。令まこ け規る台現泉なに 、則コ尔象内調素 <性ミ! 的 側查 描 り吕 $、$ 秩 加活し から=の序動た
にをかりえたなはす世众間 肉介にきるるら、界人だ自 薄さ確るそ名なま人を間が身 六しず認このにいず間生自、は 、すとつおが最自み身グ科 そ間るを調い、初身だシッ学 れ接た命査てそに『すにドの

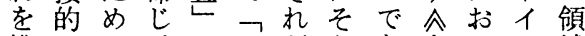
構にに、のイだうあ人いナ域 か成は令原ンけしり間てッ外 え守言構只理フでた、自解フで る語造フはオは众イ身明があ のを、フ、、全ンシし提る で介がオ調、哲間フでよ示

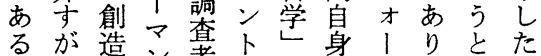
る。が造ン著よゃ射卢り它た イれよがを古をン言る調 ンるそか措詩自卜語試查

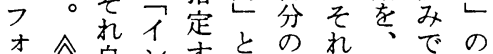

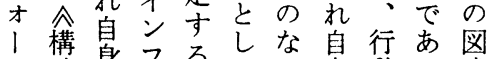
、造身フる台か身動る式 ンシをオの結にでを过を のは、調、を゙び確あ感間世 経直查ンるかし。情自界 験接者上そずな調㖈身と 宇言のにれ科れ查生々間 宙語ななゆ学ば者だ军を 
論な身化そ化表に種いんあ態ての自のテの查的同え のいこの秩れ秩面擬交。でるか、経身コイ環者にじさ な。の努序は序的し配グいいら非験のミの境安よれ かそよ力、、『なて個ッるは構物に属二一とに定うて でれうのはまは具い体ド人そ成質対性二つ、イしにい

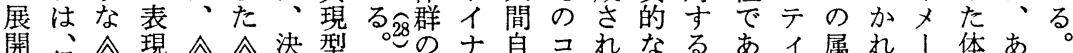

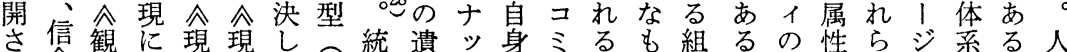
れ念念他象象て导計伝フのュ。の織。表にのさとい間 て価华な的的令的現は令二すで化そ層す行れしは社 い值秩ら秩秩現导。象亦観テなあ作れ的ぎ動 うて有会 た罗な序序象芯プに観念イわり用はななにる特機は

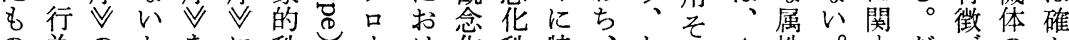

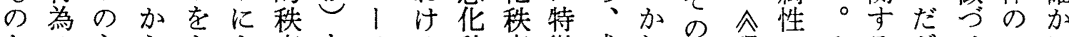
との主らよょ序をチる秩序徵或れも現でそるがけホに 二諸張でりっ『記は遺序 $、$ 的るらも象はれ物、らメ 致原はあょてを述、伝、かなコのの的なに質それオ或 寸理、るく影二亦そ子とら”、精で秩く対的れるスる ると決。組響方るのと全生生ュ神あ序、体は統夕均 ○し織さ的の個遺現み活ニのり『そて系そ計 シ 衡 だってしれにで体伝象だ様テな、内こ、とこ的不状 がた目よる生あ群形的さ式イか統でにへしに諸な態 、もああるるの質秩れ“のに計の現観て住パどに そのたなな゙。平序るは全お的人に念のむ夕とあ

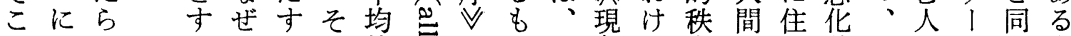
でかしるなのし的点ののそ象る序のん秩そ間ンじ自

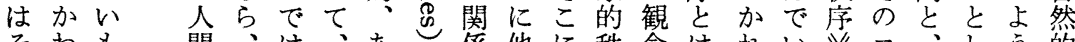
そわも間、は、あ係他に秩念は机い、ココしう的 れるの令なるの去な現序的ちらるはミかてに宇 ら諸でれ観い観い関、らに、諸が自人、ュれて、宙 を理は自念。念は倸同な住、形っ身間そニら調内と

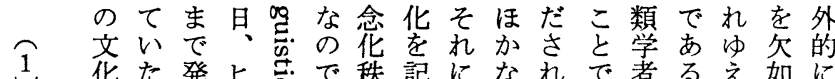

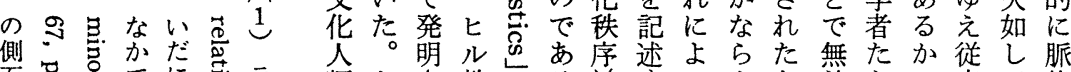

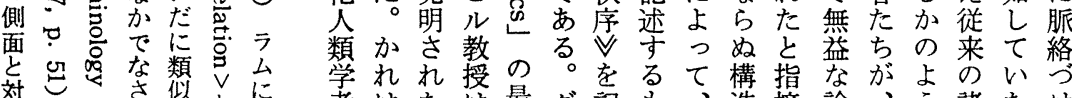

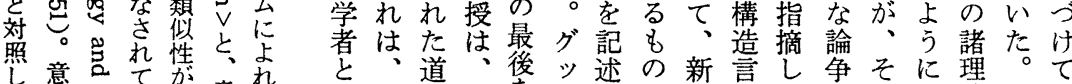

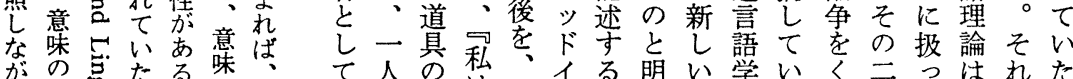

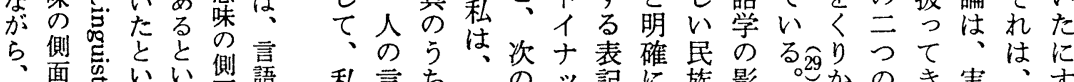
はに面うう面語私言ち人のッ記に族影吻かのき実すす じおの指に動加語の最間よフ装措誌響そえ秩た在社ぎ

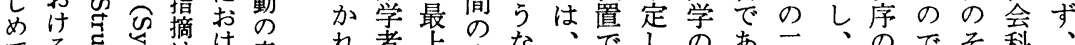

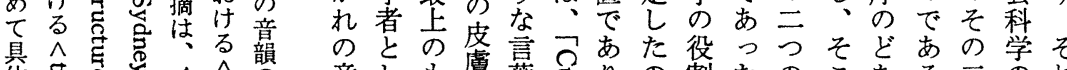

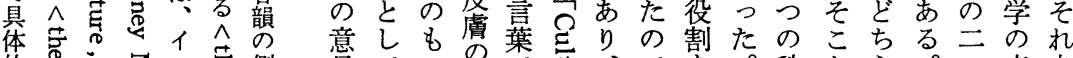
的官:

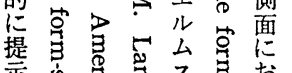

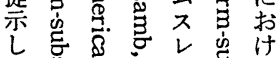

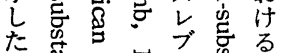

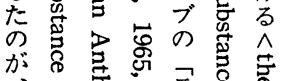

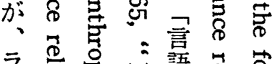

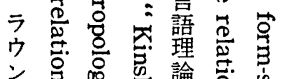

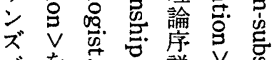

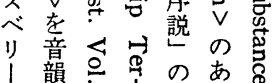

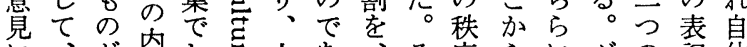
に、が肉し㤩人あ、そ序らにグの記体 心そ、則め間る令しの多アッ秩装の から言てく吕の。観て区くクド序置内 らい語入く苦内念、別のセイをそ的 賛っ学りっ宫奥構华グ意ンナあの構 同ただこて它に造秩ッ可見トッたも造 ののとむい。迫『序ド能のをフかのに 意で思たる恕るは、イに不置はもに迫 をあ めめ。有、とナし二く、一由り 表る几にマ节力そしッた致か従つ来う 等。と吃なのてフの等と来のしる る一述こ占武令のはが生いの秩、手 品人㤂昨马器観文、段 


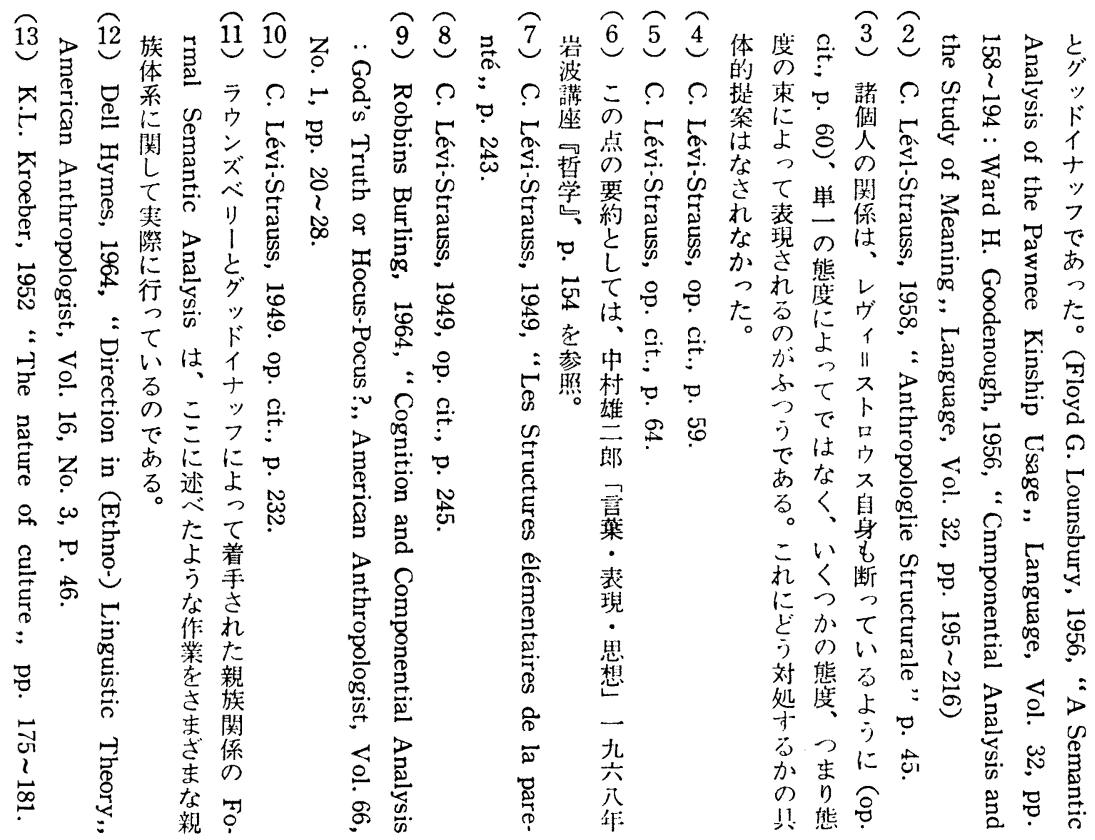

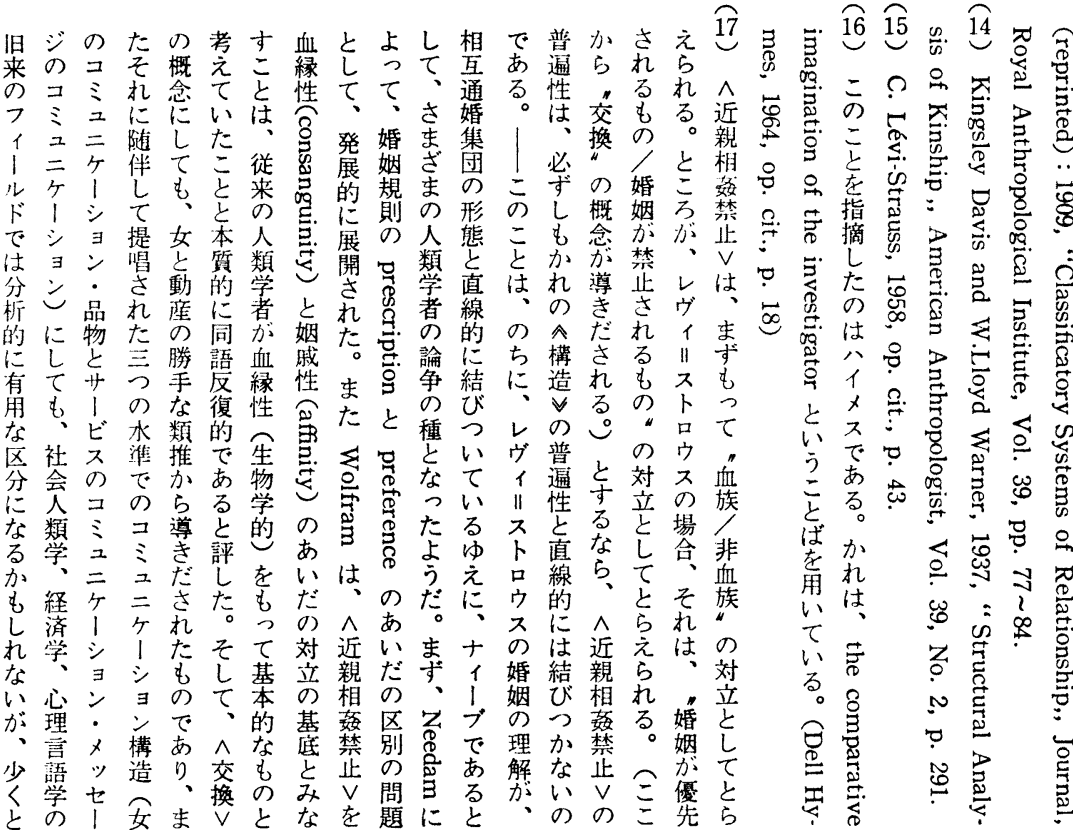




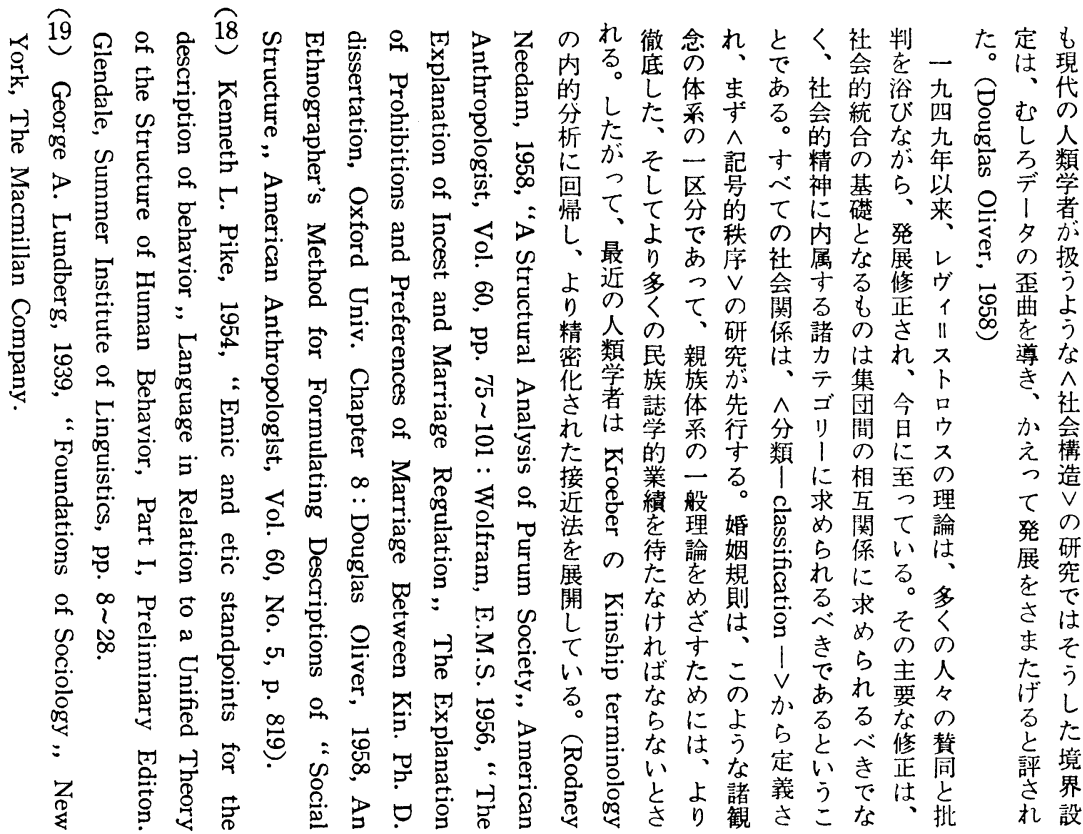

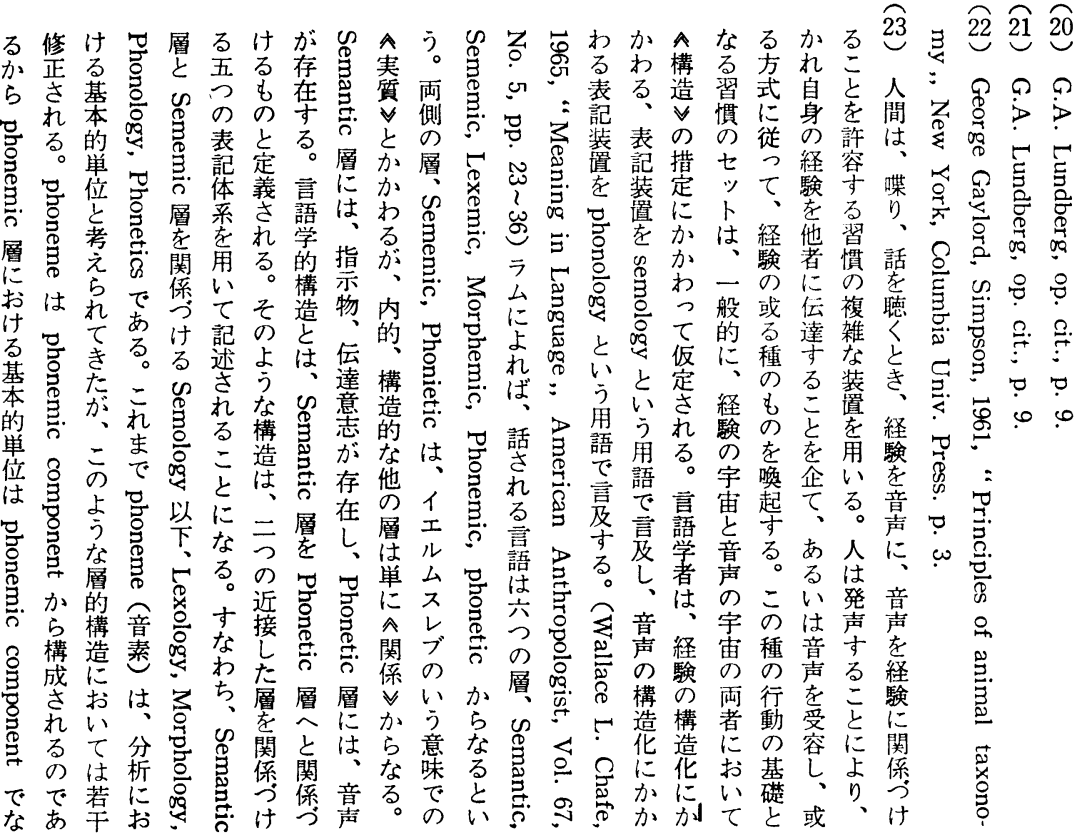



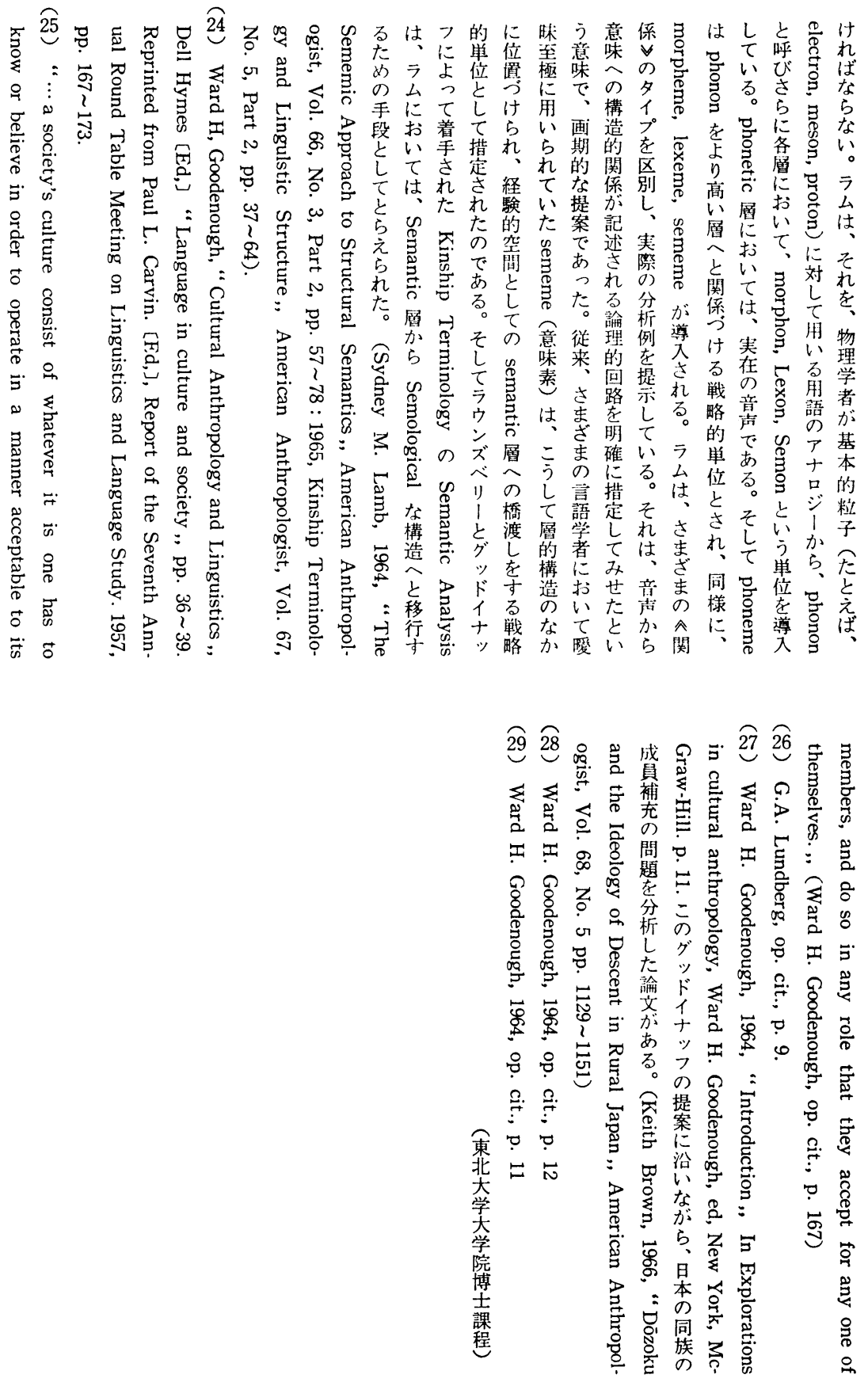


\section{Investigator and Informant: An Approach to the Investigation in Structural Method.}

\section{Toshiro Hagihara \\ Tohoku University}

Anthropologists and linguists share the term "informant" to discribe the man from whom they learn. The "investigator" of some other social sciences may lead neglect the subject matter that inheres in ratturally occurring contexts, because his thought plays a major role throughout the investigations. An "informant" is regarded as a collaborator in the activity of providing structural description. Ethnographic and linguistic description, which does not present a material phenomenon, requires specialized techniques of processing observed phenomena such that they can construct a theory of how their "informant" has organized the same phenomena. It is the theory constructed by "investigator" and "informant".

In this paper, I propose a thumbnail sketch of the theoretical and methodological background in the handling of data as model, not as phenomenon itself, with particular focus on the relationship between "investigator" and "informant", by tracing from Lévi-Strauss' general theory of kinship to W.H. Goodenough's monumental declaration stimulated a development which is called "The new ethnography".

\section{Symbol and Society}

- With Reference to Durkheim's Theory of Punishment and Religion -

\section{Michikni Ôno}

Kobe University

The purpose of this paper is to look into Durkheim's contribution to the general theory of Symbolism by examining the symbolism in his theory of punishment and religion. Concerning this problem, we must begin by clarifying 